\title{
Effects of experimental freezing on soil nitrogen dynamics in soils from a net nitrification gradient in a nitrogen-saturated hardwood forest ecosystem
}

\author{
Frank S. Gilliam, Adam Cook, and Salina Lyter
}

\begin{abstract}
This study examined effects of soil freezing on $\mathrm{N}$ dynamics in soil along an $\mathrm{N}$ processing gradient within a mixed hardwood dominated watershed at Fernow Experimental Forest, West Virginia. Sites were designated as LN (low rates of $\mathrm{N}$ processing), ML (moderately low), MH (moderately high), and HN (high). Soils underwent three 7-day freezing treatments $\left(0,-20\right.$, or $\left.-80{ }^{\circ} \mathrm{C}\right)$ in the laboratory. Responses varied between temperature treatments and along the gradient. Initial effects differed among freezing treatments for net $\mathrm{N}$ mineralization, but not nitrification, in soils across the gradient, generally maintained at $\mathrm{LN}<\mathrm{ML} \leq \mathrm{MH}<\mathrm{HN}$ for all treatments. Net $\mathrm{N}$ mineralization potential was higher following freezing at -20 and $-80{ }^{\circ} \mathrm{C}$ than control; all were higher than at $0{ }^{\circ} \mathrm{C}$. Net nitrification potential exhibited similar patterns. $\mathrm{LN}$ was an exception, with net nitrification low regardless of treatment. Freezing response of $\mathrm{N}$ mineralization differed greatly from that of nitrification, suggesting that soil freezing may decouple two processes of the soil $\mathrm{N}$ cycle that are otherwise tightly linked at our site. Results also suggest that soil freezing at temperatures commonly experienced at this site can further increase net nitrification in soils already exhibiting high nitrification from $\mathrm{N}$ saturation.
\end{abstract}

Résumé : Nous avons étudié les effets du gel du sol sur la dynamique de $\mathrm{N}$ dans le sol le long d'un gradient de transformation de $\mathrm{N}$ dans un bassin versant dominé par des feuillus mélangés à la Forêt expérimentale de Fernow, en Virginie-Occidentale. Les stations ont été classées sur la base du taux de transformation de N: LN (faible), ML (modérément faible), $\mathrm{MH}$ (modérément élevé) et $\mathrm{HN}$ (élevé). Les sols ont subi trois périodes de gel de 7 jours $\left(0,-20\right.$ ou $\left.-80{ }^{\circ} \mathrm{C}\right)$ en laboratoire. Les réactions ont varié selon la température ainsi que le long du gradient. Les effets initiaux étaient différents selon l'intensité du gel dans le cas de la minéralisation nette mais pas dans le cas de la nitrification dans les sols le long du gradient qui s'est généralement maintenu à $\mathrm{LN}<\mathrm{ML}<\mathrm{MH}<\mathrm{HN}$ avec tous les traitements. Le potentiel de minéralisation nette de $\mathrm{N}$ était plus élevé à la suite d'un gel à -20 et $-80{ }^{\circ} \mathrm{C}$ que chez le témoin et plus élevé qu'à $0{ }^{\circ} \mathrm{C}$ dans tous ces traitements. Le potentiel de nitrification nette suivait le même patron. La station LN faisait exception: la nitrification nette était faible peu importe le traitement. La réponse de la minéralisation de $\mathrm{N}$ au gel était très différente de celle de la nitrification, indiquant que le gel du sol peut découpler deux processus du cycle de $\mathrm{N}$ dans le sol qui sont par ailleurs étroitement reliés dans notre site. Les résultats indiquent aussi que le gel du sol à des températures qui surviennent couramment dans ce site peut augmenter davantage la nitrification nette dans les sols où la nitrification est déjà élevée à cause de la saturation en $\mathrm{N}$.

[Traduit par la Rédaction]

\section{Introduction}

Among the paradoxes of global warming is a predicted increase in the likelihood of soils of north-temperate forests to freeze during winter months (Groffman et al. 2001a). This has important implications for the structure and function of forest ecosystems because freezing can alter several biogeochemical processes in affected forest soils, particularly those involved with $\mathrm{N}$ cycling in forest ecosystems. Freezing of soil can drastically influence the mobility and availability of $\mathrm{N}$ in forest soils by affecting microbial populations responsible for transforming unavailable organic $\mathrm{N}$ into mobile, available forms (Allen-Morley and Coleman 1989). This response is similar to that of drying-rewetting cycles (Skogland et al. 1988; DeLuca et al. 1992), which have been shown to substantially increase extractable $\mathrm{NO}_{3}$ from nearly undetectable levels in N-limited soils (Gilliam and Richter 1985, 1988). A burst of microbial activity generally accompanies both thawing of frozen soil and rewetting of dried soil (Skogland et al. 1988).

In temperate forests, particularly those in more northern latitudes, snow cover acts seasonally as an effective insulator for soil by virtue of its high air content, mitigating the effects of low air temperature on soil, typically preventing

Received 11 August 2009. Accepted 11 December 2009. Published on the NRC Research Press Web site at cjfr.nrc.ca on 24 February 2010 .

F.S. Gilliam, ${ }^{1}$ A. Cook, and S. Lyter. Department of Biological Sciences, Marshall University, 400 Hal Greer Boulevard, Huntington, WV 25755-2510, USA.

${ }^{1}$ Corresponding author (e-mail: gilliam@marshall.edu). 
soil from freezing and ensuring survival of a variety of microorganisms beneath snow cover (Schimel et al. 2004; Schmidt et al. 2009). Consequently, soils that are overlain by snowpack frequently go through winter months without freezing, despite extremes of low air temperatures (LynchStieglitz 1994). Conversely, soils commonly freeze in forests of northern latitudes in the absence of snow. Working in hardwood and conifer forests of New Hampshire, Fahey and Lang (1975) found that the occurrence of soil freezing increased with elevation, varied with stand type, and lasted as late as May and June in that region.

Global warming has been causally connected to recent decreases in snowfall in north-temperate forests (Barnett et al. 2005). Long-term data from the Hubbard Brook Experimental Forest, New Hampshire, indicate that from 1955 to 2005, all measures of snow fall (i.e., depth, water content, and duration of cover) decreased significantly with time (Campbell et al. 2007). Thus, the frequency of soil freezing events is likely to increase in the future (Hardy et al. 2001).

Experimental approaches to investigate effects of freezing on soil have varied considerably in the literature. Morley et al. (1983) used extreme freeze-thaw cycles $\left(-27\right.$ to $\left.23{ }^{\circ} \mathrm{C}\right)$ in the laboratory that resulted in $40 \%-60 \%$ mortality of bacterial populations. Investigating freezing effects on soil food webs, Allen-Morley and Coleman (1989) subjected soil to $-1{ }^{\circ} \mathrm{C}$ for 7 days and found that postfreezing recovery varied greatly among soil microbial populations. Cooke (1990) used liquid $\mathrm{N}_{2}$ to freeze contrasting soil types, finding that effects of freezing on nitrification enzyme activity varied greatly with type of soil.

In 1996, a snowpack manipulation experiment was established at Hubbard Brook Experimental Forest to examine the biogeochemical consequences of decreases in snowpack accumulation (Groffman et al. 2001a). This study found that even mild winters can bring about soil freezing in the absence (i.e., experimental removal) of snowpack (Hardy et al. 2001). It also determined that soil freezing increased mortality of fine roots (Tierney et al. 2001), increased soil $\mathrm{NO}_{3}$ without significantly altering net $\mathrm{N}$ mineralization and nitrification (Groffman et al. 2001b), and enhanced loss of $\mathrm{N}$ and $\mathrm{P}$ via soil solution (Fitzhugh et al. 2001).

Christopher et al. (2008) studied the effects of soil freezing on $\mathrm{N}$ mineralization and nitrification by sampling along a snow-cover gradient in Japan, sampling in contrasting soil types. They found simultaneous increases in $\mathrm{N}$ mineralization and decreases in nitrification in response to freezing, regardless of soil type. Austnes and Vestgarden (2008) used an experimental approach to examine the response of $\mathrm{N}$ in undisturbed soil columns from montane heathlands of southern Norway to freeze-thaw cycle and permanent frost treatments, finding that both treatments increased $\mathrm{NH}_{4}$ and decreased $\mathrm{NO}_{3}$. In another freeze-thaw experiment, Joseph and Henry (2008) found that $\mathrm{N}$ leaching increased nearly twofold following freezing and thawing of temperate old field soils.

This latter response, increased leaching of $\mathrm{N}$ in the form of $\mathrm{NO}_{3}$, has important relevance to effects of freezing in soils of $\mathrm{N}$-saturated forest ecosystems wherein soil $\mathrm{NO}_{3}$ accumulates and is leached from soil into streams (Aber et al. 1998). This can be of serious concern to forest health if more frequent freezing events further increase $\mathrm{NO}_{3}$ leaching because it has been shown to deplete $\mathrm{Ca}$ and $\mathrm{Mg}$ availability in impacted soils (Peterjohn et al. 1996; Gilliam et al. $2001 a, 2001 b, 2005)$. We are aware of no studies that have examined effects of freezing on $\mathrm{N}$ dynamics in soils of $\mathrm{N}$ saturated forests.

Several hardwood-dominated watersheds of the Fernow Experimental Forest (FEF), West Virginia, have been shown to be $\mathrm{N}$ saturated (Gilliam et al. 1996; Peterjohn et al. 1996), particularly the long-term reference watershed at FEF (WS4) (Stoddard 1994; Gress et al. 2007). Another symptom of $\mathrm{N}$ saturation, that of high relative nitrification (i.e., the percent of mineralized $\mathrm{N}$ converted to $\mathrm{NO}_{3}$ ), is especially evident at FEF. Long-term in situ (buried bag) incubations have revealed that nitrification is consistently close to $100 \%$ across three FEF watersheds, indicating that net $\mathrm{N}$ mineralization and nitrification are tightly linked at this site (Gilliam et al. 2001a, 2001b, 2004).

In addition, a notable degree of spatial heterogeneity in soil N dynamics has been described for WS4 as evidenced by spatial patterns of soil solution chemistry and in situ incubations (Peterjohn et al. 1999; Gilliam et al. 2001a, $2001 b$, 2005). Based on long-term data for soil water $\mathrm{NO}_{3}$ and in situ rates of net nitrification, we have identified a gradient of four sites within WS4 that vary in rates of $\mathrm{NO}_{3}$ production.

The purpose of this study was to examine the effects of soil freezing on net $\mathrm{N}$ mineralization and nitrification along a gradient of rates of $\mathrm{N}$ processing in an $\mathrm{N}$-saturated central hardwood forest ecosystem. We subjected soil samples to three freezing temperature treatments, $0,-20$, and $-80{ }^{\circ} \mathrm{C}$, addressing the following questions. (i) What are the initial effects of soil freezing on $\mathrm{NH}_{4}$ and $\mathrm{NO}_{3}$ production? (ii) What are the effects of soil freezing on net $\mathrm{N}$ mineralization and nitrification potentials and relative nitrification? (iii) How do these responses vary along the nitrification gradient?

\section{Materials and methods}

\section{Study site}

The study site, FEF, occupies $~ 1900$ ha of the Allegheny Mountain section of the unglaciated Allegheny Plateau in Tucker County, West Virginia, adjacent to the Monongahela National Forest $\left(39^{\circ} 03^{\prime} \mathrm{N}, 79^{\circ} 49^{\prime} \mathrm{W}\right)$. Averaging approximately $1430 \mathrm{~mm} \cdot$ year $^{-1}$, precipitation at FEF varies seasonally and with elevation, generally greater during the growing season and at higher elevations (Gilliam et al. 1996). Longterm records at FEF indicate that, for the decade of 19912000 , there were $>1100$ days with ambient temperatures $<0{ }^{\circ} \mathrm{C}$. Of these, nearly $20 \%$ were less than $-10{ }^{\circ} \mathrm{C}$. Snowpack typically ranges from a few days to $<2$ weeks (Adams et al. 1994). Thus, the likelihood of freezing is notable for this site.

Four sample sites were located in WS4, the long-term reference watershed at FEF that supports >100-year-old mixed-aged hardwood stands (Fig. 1). Soils at all sample sites are predominantly coarse-textured Inceptisols (loamyskeletal, mixed mesic Typic Dystrochrept) of the Berks and Calvin series, sandy loams derived from sandstone. Soil $\mathrm{pH}$ generally varies between 3.50 and 4.00 (Gilliam et al. 2004). The woody overstory is characterized by a high diversity of tree species, with dominant species including sugar maple 
Fig. 1. Map of WS4 of Fernow Experimental Forest, West Virginia, showing sample sites for the present study. Sites are as follows: low nitrification (LN), medium-low nitrification (ML), mediumhigh nitrification $(\mathrm{MH})$, and high nitrification $(\mathrm{HN})$.

50 metres

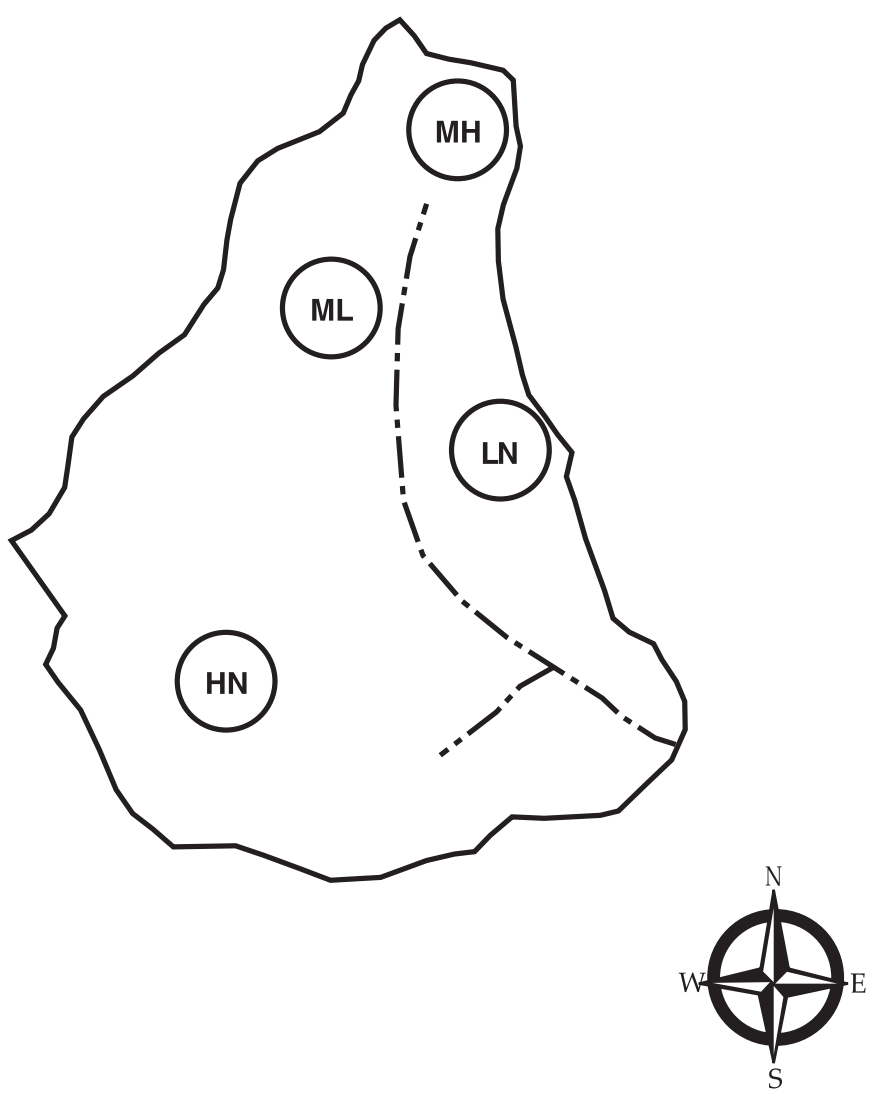

(Acer saccharum Marsh.), black cherry (Prunus serotina Ehrh.), and northern red oak (Quercus rubra L.). The herbaceous layer of these sites comprises species typical of montane eastern deciduous forests, including violets (Viola spp.), blackberry (Rubus spp.), stinging nettle (Laportea canadensis (L.) Wedd.), and several species of ferns (Gilliam 2007).

\section{Field sampling}

Sampling was done at four sites that were shown by previous investigations to represent a gradient in rates of net nitrification. Determination of this gradient was based on long-term soil water $\mathrm{NO}_{3}$ data and 6 years of monthly (growing season) rates of net $\mathrm{N}$ mineralization and nitrification measured in situ from 1993 to 2007 and reported in part in Gilliam et al. $(2001 a, 2001 b)$. The sites were not defined by specific boundaries, thus precluding accurate estimates of area. Rather, they were identified as essentially subcatchments within the watershed. These sites were as follows: $\mathrm{LN}$ (low rates of $\mathrm{N}$ processing), ML (medium-low rates), $\mathrm{MH}$ (medium-high rates), and $\mathrm{HN}$ (high rates). Several stand and soil characteristics of the four sites are summarized in Table 1.

Mineral soil was taken to a $5 \mathrm{~cm}$ depth as nine replicate samples from a randomly located $3 \mathrm{~m} \times 3 \mathrm{~m}$ grid at each site. The grid was located at each site adjacent to the long- term in situ incubation plot to reflect the soil characteristics (see Table 1) reported previously in the literature (Gilliam et al. 2001a, 2001b). The grid design was used as part of an additional study on microscale heterogeneity in soil processes. A single sample was taken at the center of each of nine $1 \mathrm{~m}^{2}$ contiguous plots within the grid. Soil was removed via hand trowel and placed in $500 \mathrm{~mL}$ sterile polyethylene Whirl-Pac bags, which were stored on ice for transport back to the Marshall University Weeds and Dirt Laboratory.

\section{Experimental treatments}

Subsamples of soil from each plot were extracted for analysis of $\mathrm{NH}_{4}^{+}$and $\mathrm{NO}_{3}^{-}$immediately upon return to the laboratory (see Laboratory analyses below). Approximately $50 \mathrm{~g}$ of each sample was placed into each of three $120 \mathrm{~mL}$ sterile polyethylene Whirl-Pac bags for freezing treatment as follows: $0,-20$, and $-80{ }^{\circ} \mathrm{C}$. The 0 and $-20{ }^{\circ} \mathrm{C}$ treatments were administered by placing bags in separate Fisher Isotemp incubators, which held soil temperature constant at the respective settings. The $-80{ }^{\circ} \mathrm{C}$ treatment was administered by placing bags in a Thermo Electron Corporation freezer and was chosen as an extreme treatment to determine whether the intermediate treatment $\left(-20{ }^{\circ} \mathrm{C}\right)$ represents a threshold temperature for freezing effects (i.e., slight or no differences between -20 and $-80{ }^{\circ} \mathrm{C}$ treatments would suggest a $-20{ }^{\circ} \mathrm{C}$ threshold). The remaining soil was kept in the original bag and refrigerated at $4{ }^{\circ} \mathrm{C}$ as control. All treated samples were subjected to treatments for 7 days.

Initial effects of freezing on soil $\mathrm{N}$ were assessed in this study to further separate the direct biotic and abiotic effects of freezing. These effects were assessed by extracting all treated samples immediately following thawing for $24 \mathrm{~h}$ (note: the $0{ }^{\circ} \mathrm{C}$ soils did not freeze to hardness due to the freezing point depression effect of soil solutes but were allowed to come to room temperature for the same time period as for the -20 and $-80{ }^{\circ} \mathrm{C}$ samples). Effects of freezing treatment on net $\mathrm{N}$ mineralization and nitrification potential were assessed by incubating the remaining soil in all bags for 7 days at $25{ }^{\circ} \mathrm{C}$ prior to additional extraction.

\section{Laboratory analyses}

Soil moisture was monitored for all subsamples before and during incubation, and neither varied among samples or through time of incubation. Extraction and analysis for $\mathrm{NH}_{4}^{+}$ and $\mathrm{NO}_{3}^{-}$followed methods described in Gilliam et al. (2005). Briefly, moist soils were extracted with $1 \mathrm{~mol} \cdot \mathrm{L}^{-1}$ $\mathrm{KCl}$ at an extract to soil ratio of $10: 1(\mathrm{v} / \mathrm{m})$; these were expressed as dry mass using a dry to moist conversion ratio from dried subsamples. Extracts were analyzed colorimetrically for $\mathrm{NH}_{4}^{+}$and $\mathrm{NO}_{3}^{-}$with an AutoAnalyzer 3 automatic analysis system. Net $\mathrm{N}$ mineralization rates (in $\mu \mathrm{g} \mathrm{N} \cdot \mathrm{g}$ soil $^{-1} \cdot$ day $^{-1}$ ) were calculated as postincubation $\mathrm{NH}_{4}^{+}$and $\mathrm{NO}_{3}^{-}$minus preincubation $\mathrm{NH}_{4}^{+}$and $\mathrm{NO}_{3}^{-}$. Nitrification rates (in $\mu \mathrm{g} \mathrm{N} \cdot \mathrm{g}$ soil $^{-1} \cdot \mathrm{day}^{-1}$ ) were calculated as postincubation $\mathrm{NO}_{3}^{-}$minus preincubation $\mathrm{NO}_{3}^{-}$. Relative nitrification was expressed as a percentage and calculated as net nitrification divided by net $\mathrm{N}$ mineralization multiplied by 100 .

\section{Data analyses}

The effects of freezing on net $\mathrm{N}$ mineralization and nitri- 
Table 1. Characteristics of sample sites along a net nitrification gradient within WS4 of Fernow Experimental Forest, West Virginia.

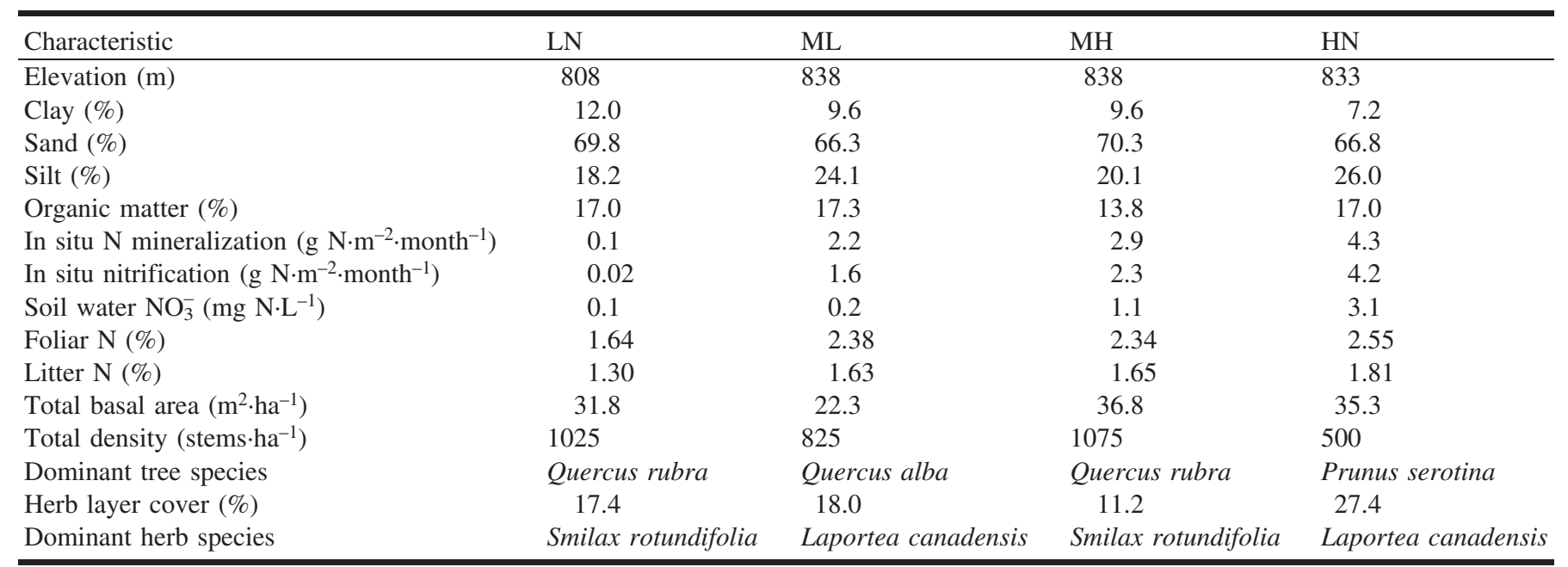

Note: Sites: low nitrification (LN), medium-low nitrification (ML), medium-high nitrification (MH), and high nitrification (HN). $\mathrm{N}$ data taken from ongoing work initially reported in Gilliam et al. $(2001 a, 2001 b)$.

fication were assessed by comparing means of control soils with those of soils treated at $0,-20$, and $-80{ }^{\circ} \mathrm{C}$ with oneway analysis of variance and least significant difference tests (Zar 1999). We considered initial effects of freezing to be any treatment effect found for extractions made immediately after freezing treatment. Effects of freezing on potential net $\mathrm{N}$ mineralization and net nitrification were said to be those found for extractions made following the 1-week incubation of all soils at $25{ }^{\circ} \mathrm{C}$. Potential effects of soil weathering on net nitrification were assessed via correlation between mean nitrification and mean soil clay content across all four sites.

\section{Results and discussion}

\section{Initial effects of freezing on net $\mathbf{N}$ mineralization and nitrification}

Laboratory freezing exerted pronounced initial effects on net $\mathrm{N}$ mineralization, although this effect varied significantly $(P<0.05)$ among sites (Fig. 2$)$. Initial effects differed significantly among freezing temperatures for net $\mathrm{N}$ mineralization, but not nitrification, in soils across the gradient, which was generally maintained for all freezing treatments (i.e., rates of $\mathrm{N}$ processing at $\mathrm{LN}<\mathrm{ML} \leq \mathrm{MH}<\mathrm{HN}$ ). An exception to these patterns was evident for the LN site wherein net nitrification remained very low across all freezing treatments (Fig. 2). Net $\mathrm{N}$ mineralization was highest at $-80{ }^{\circ} \mathrm{C}$ for the higher $\mathrm{N}$ sites and was significantly lowest across all sites at $0{ }^{\circ} \mathrm{C}$.

Initial responses of soil $\mathrm{N}$ to freezing (i.e., immediately after freezing treatment) were assessed in this study because they should exemplify the direct biotic and abiotic effects of freezing. Biotic effects include responses of microbial populations associated in soil $\mathrm{N}$ dynamics, which may initially decrease due to lysing of cells from ice formation in the cytosol, simultaneously increasing $\mathrm{NH}_{4}$ and $\mathrm{NO}_{3}$ that is released from the cytosol (Allen-Morley and Coleman 1989). Also, $\mathrm{NH}_{4}$ production following cell lysis is possible through extracellular deaminase activity (Abdel-Fatah et al. 2003). Abiotically, freeze-thaw cycles facilitate physical
Fig. 2. Initial effects of freezing on $(a)$ net $\mathrm{N}$ mineralization and (b) net nitrification of soils from four sites within WS4 of the Fernow Experimental Forest, West Virginia. Experimental treatments are as follows: low freeze (T0, freezing at $0{ }^{\circ} \mathrm{C}$ for 7 days followed by incubation), medium freeze (T-20, freezing at $-20{ }^{\circ} \mathrm{C}$ followed by incubation), and high freeze (T-80, freezing at $-80{ }^{\circ} \mathrm{C}$ followed by incubation). Shown are means $\pm 1 \mathrm{SE}$ of the mean. Means with the same letter $(\mathrm{x}, \mathrm{y}, \mathrm{z})$ are not significantly different $(P<0.05)$ between sites for a given treatment. Means with same letter (a, b, c) are not significantly different $(P<0.05)$ between treatments for a given site.
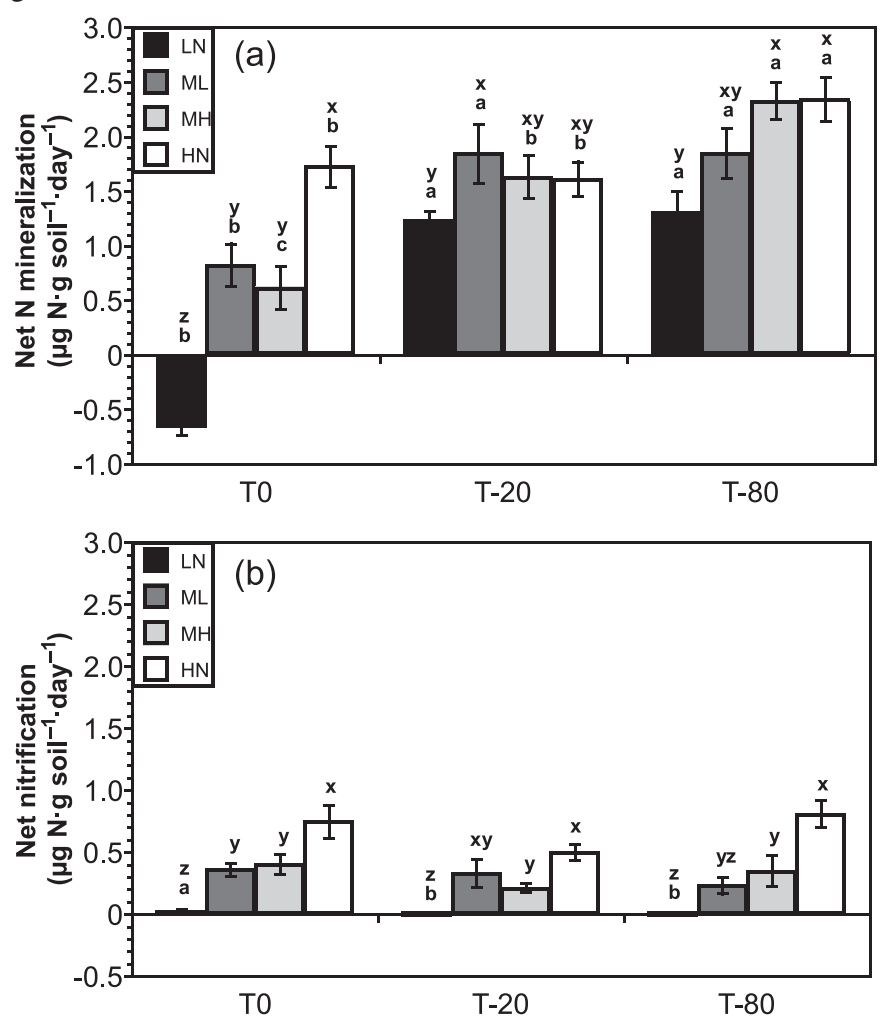
breakdown of soil organic matter, increasing surface area to volume ratios of soil organic materials and increasing accessibility to microbes.

\section{Effects of freezing on net $\mathrm{N}$ mineralization and net nitrification potentials}

Net $\mathrm{N}$ mineralization potential (hereafter, net $\mathrm{N}$ mineralization) (i.e., following a 7-day incubation at $25^{\circ} \mathrm{C}$ ) was significantly higher following freezing at -20 and $-80{ }^{\circ} \mathrm{C}$ than the control, which was also significantly higher than the $0{ }^{\circ} \mathrm{C}$ treatment. A similar pattern was observed for net nitrification potential (hereafter, net nitrification), i.e., rates following $-20^{\circ} \mathrm{C} \approx-80^{\circ} \mathrm{C}>$ control $>0{ }^{\circ} \mathrm{C}$ (Fig. 3). Also, means among sites generally maintained the gradient pattern based on field data. That is, net nitrification was consistently highest at $\mathrm{HN}$, lowest at $\mathrm{LN}$, and intermediate at the ML and $\mathrm{MH}$ sites. More specifically, net nitrification at the LN site was consistently one to two orders of magnitude lower, ranging from 0.01 to $0.05 \mu \mathrm{g} \mathrm{N} \cdot \mathrm{g}$ soil $^{-1}$. $\mathrm{day}^{-1}$, than at the HN site, which ranged between $\sim 3.0$ and $5.0 \mu \mathrm{g} \mathrm{N} \cdot \mathrm{g}$ soil $^{-1}$. day ${ }^{-1}$ (Fig. 3).

Thus, whereas freezing treatments that resulted in a truly frozen state (i.e., -20 and $-80{ }^{\circ} \mathrm{C}$ ) increased net $\mathrm{N}$ mineralization and nitrification relative to controls, these processes were significantly inhibited at $0{ }^{\circ} \mathrm{C}$. This may have arisen from two mechanisms. First, the $0{ }^{\circ} \mathrm{C}$ treatment may have suppressed $\mathrm{N}$ mineralization but not $\mathrm{N}$ immobilization, thus increasing the level of net $\mathrm{N}$ immobilization. Second, populations of ammonifying microbes and nitrifying bacteria may have decreased at $0{ }^{\circ} \mathrm{C}$ in a way that limited their response to the increasing temperature of incubation $\left(25^{\circ} \mathrm{C}\right)$. Significant increases in both net $\mathrm{N}$ mineralization and nitrification at -20 and $-80{ }^{\circ} \mathrm{C}$ suggest that microbial cellular constituents (from cell lysis) and increased surface area of soil organic matter from the physical action of ice provided sufficient substrate to allow these populations to overcome low-temperature limitations.

It is of great interest that there were no significant differences in net $\mathrm{N}$ mineralization and nitrification between the 20 and $-80{ }^{\circ} \mathrm{C}$ treatments. Generally outside the realm of surface temperatures of the biosphere (lowest natural temperature was $-89.2{ }^{\circ} \mathrm{C}$ recorded 21 July 1983 at the Russian Vostok Station in Antarctica), the $-80{ }^{\circ} \mathrm{C}$ treatment was used to test whether further decreasing temperature in a fully frozen state would have a proportional effect on soil $\mathrm{N}$ dynamics. Our results suggest that $-20{ }^{\circ} \mathrm{C}$ may represent threshold beyond which further decreases in temperature bring about minimal changes in microbial $\mathrm{N}$ processing. Clearly, freezing at $-80{ }^{\circ} \mathrm{C}$ does not bring about notable declines in nitrifier populations, such as Nitrosomonas and $\mathrm{Ni}$ trobacter, at least not in soils with highly active populations, such as those that are predominant at the HN site (Gilliam et al. 2001a, 2001b).

Results vary considerably among studies in the literature that examine effects of freezing on soil N. Harding and Ross (1964) found that thawing after freezing at $-20{ }^{\circ} \mathrm{C}$ increased net $\mathrm{N}$ mineralization and nitrification in some, but not all, soils examined, concluding that moisture and $\mathrm{C}$ contents of soils may influence this response. The field-based snow manipulation study at Hubbard Brook Experimental Forest found that freezing (brought about by experimentally removing snowpack) resulted in increases in soil $\mathrm{NO}_{3}$ and
Fig. 3. Effects of freezing on (a) potential net $\mathrm{N}$ mineralization and (b) potential net nitrification of soils from four sites within WS4 of the Fernow Experimental Forest, West Virginia. Control (C), no treatment followed by 7 days of incubation at $25^{\circ} \mathrm{C}$; see Fig. 2 for experimental treatments. Shown are means $\pm 1 \mathrm{SE}$ of the mean. Means with the same letter $(\mathrm{x}, \mathrm{y}, \mathrm{z})$ are not significantly different $(P<0.05)$ between sites for a given treatment. Means with the same letter $(\mathrm{a}, \mathrm{b}, \mathrm{c})$ are not significantly different $(P<0.05)$ between treatments for a given site.
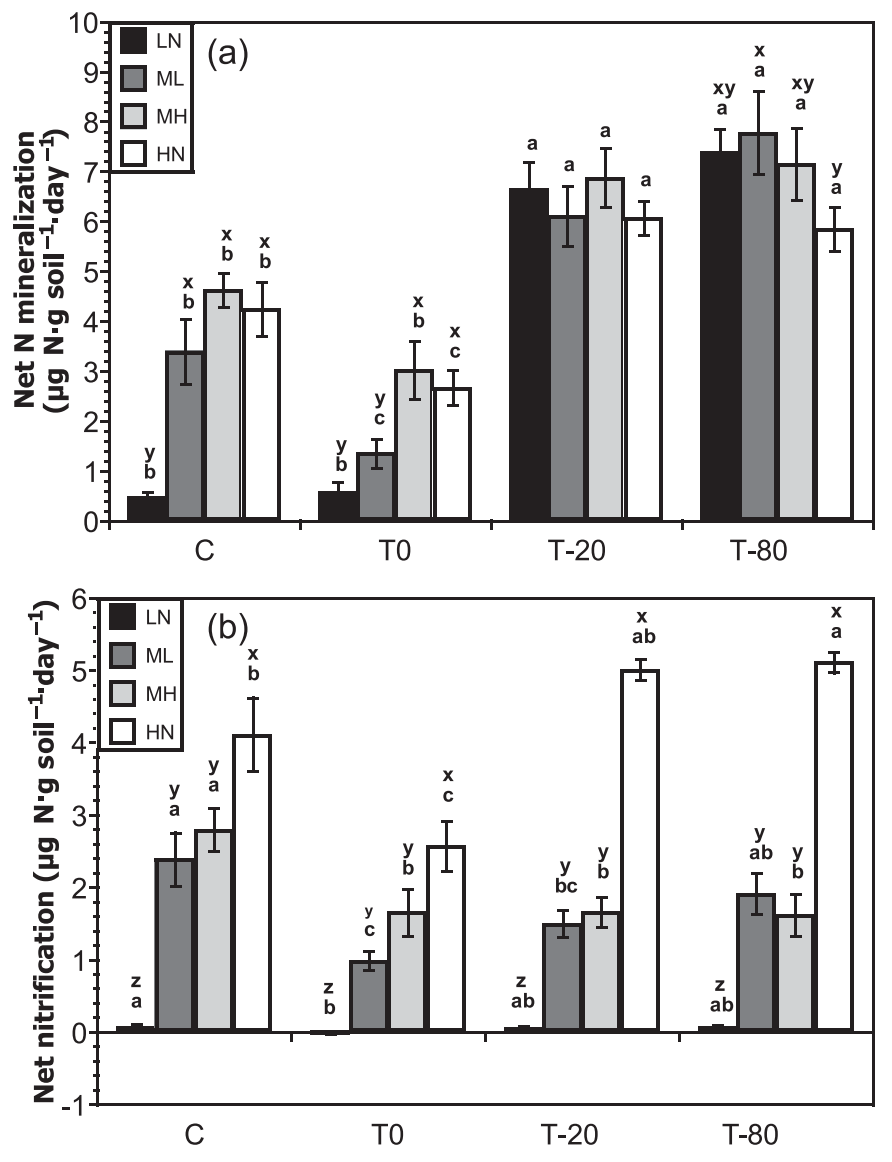

enhanced loss of $\mathrm{N}$ in soil solution, but did so without significantly influencing net nitrification (Fitzhugh et al. 2001; Groffman et al. 2001a, 2001b). Joseph and Henry (2008) found that experimental freeze-thaw cycles of temperate old field soils increased leaching of $\mathrm{N}$ nearly twofold. By contrast, Hentschel et al. (2009) concluded that moderate soil frost did not stimulate solute losses of $\mathrm{N}$, dissoved organic $\mathrm{C}$, and mineral ions from soils of montane Norway spruce (Picea abies (L.) Karst.) stands around Fichtelgebirge, Germany.

The degree to which net $\mathrm{N}$ mineralization and net nitrification are coupled (sensu Christopher et al. 2008) can be assessed by calculating relative nitrification. Robertson (1982) used relative nitrification as an independent test of site factors (e.g., soil $\mathrm{pH}, \mathrm{C}$ to $\mathrm{N}$ ratio) that potentially influence in situ nitrification. Relative nitrification has been shown to vary considerably with stand type, with much higher relative nitrification generally associated with hardwood than with conifer forests (Bonilla and Rodà 1992; Gilliam et al. 2004; Fenn et al. 2005). High relative nitrification also has been 
Fig. 4. Effects of freezing on relative nitrification (i.e., fraction (percent) of mineralized $\mathrm{N}$ that is nitrified) of incubated soils from four sites within WS4 of the Fernow Experimental Forest, West Virginia. See Fig. 2 for experimental treatments. Shown are means $\pm 1 \mathrm{SE}$ of the mean. Means with the same letter $(\mathrm{w}, \mathrm{x}, \mathrm{y}, \mathrm{z})$ are not significantly different $(P<0.05)$ between sites for a given treatment. Means with the same letter $(\mathrm{a}, \mathrm{b}, \mathrm{c})$ are not significantly different $(P<0.05)$ between treatments for a given site.

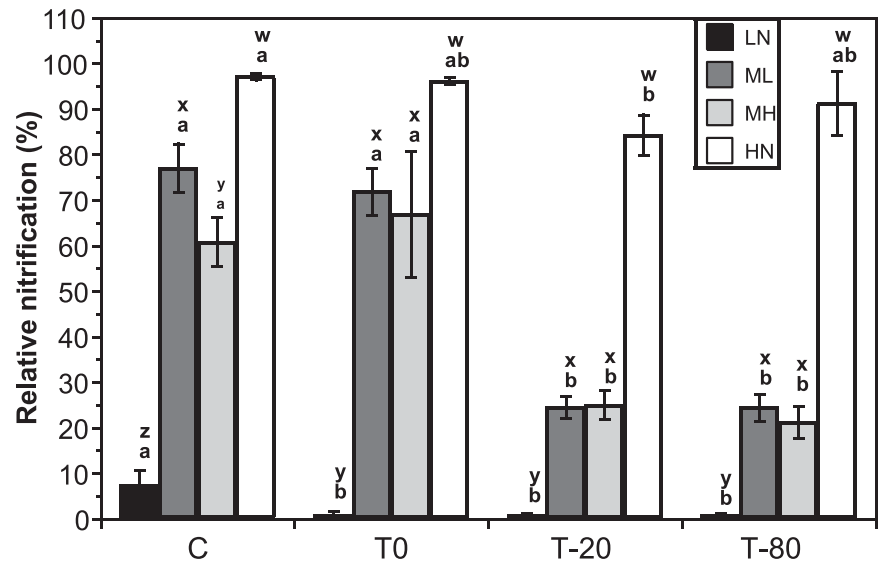

linked to high rates of $\mathrm{N}$ deposition (Fenn et al. 2005) and $\mathrm{N}$ saturation (Gilliam et al. 2004).

Mean relative nitrification for the control treatment confirms earlier findings that net nitrification can be as high as $100 \%$ of net $\mathrm{N}$ mineralization in these soils (Gilliam et al. $2001 a$, 2001b, 2004). Mean values varied significantly among sites, however, in the following order: $\mathrm{HN}(97 \%)>$ ML $(77 \%)>\mathrm{MH}(61 \%)>\mathrm{LN}(7 \%)$, with the general effect of freezing being to decrease relative nitrification (Fig. 4). All freezing treatments significantly decreased relative nitrification at the $\mathrm{LN}$ site. Freezing at -20 and $-80{ }^{\circ} \mathrm{C}$, but not at $0{ }^{\circ} \mathrm{C}$, caused significant decreases at the $\mathrm{ML}$ and $\mathrm{MH}$ sites, whereas $-20{ }^{\circ} \mathrm{C}$ (but neither 0 nor $-80{ }^{\circ} \mathrm{C}$ ) significantly decreased relative nitrification at the $\mathrm{HN}$ site (Fig. 4). Therefore, we conclude that soil freezing may serve to decouple two processes of the soil $\mathrm{N}$ cycle that can otherwise be tightly linked at our site, similar to the conclusions of Christopher et al. (2008).

\section{Gradient factors}

It is notable that the gradient pattern in net nitrification based on long-term in situ incubations (Table 1) was generally maintained under the controlled conditions in the laboratory (Figs. $2 b$ and $3 b$ ). This strongly suggests that the gradient patterns observed from the field have arisen from variation in soil microbial communities (i.e., composition and activity) of the respective sites rather than the more transient ambient factors, such as moisture and temperature, that are otherwise important in controlling microbial processes (Gilliam et al. 2001a, 2001b). Accordingly, we were interested in determining which, if any, site variables, many of which are listed as "Characteristics" in Table 1, might best explain this gradient pattern. Of these, soil clay content was correlated most closely with net nitrification across the four sites, independent of treatment (Fig. 5). Furthermore, there is considerable evidence to suggest that this gradient is the product of differential rates of mineral weathering
Fig. 5. Second-order polynomial relationships between net nitrification and clay content following 1-week incubations for the following freezing treatments: control $(\mathrm{C})\left(r^{2}=0.989, P<0.01\right), 0{ }^{\circ} \mathrm{C}$ (T0) $\left(r^{2}=0.938, P<0.05\right),-20{ }^{\circ} \mathrm{C}$ (T20) $\left(r^{2}=0.999, P<0.01\right)$, and $-80{ }^{\circ} \mathrm{C}\left(r^{2}=0.997, P<0.01\right)$.

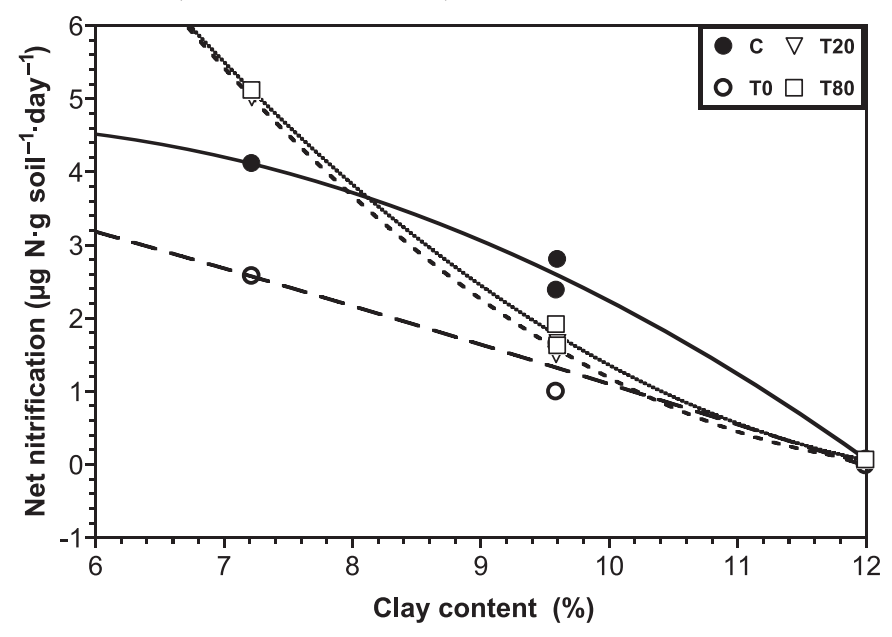

during the process of soil formation (Jenny 1980). For example, although soils of WS4 are underlain by the same parent material (Gilliam et al. 2005), Tajchman et al. (1988) demonstrated that over a 35-year period (1948-1982), net radiation, a principle driver in weathering of primary and secondary soil materials (Jenny 1980; Rech et al. 2001), was highest on southwest-facing upper slopes of the watershed and lowest on the north- and northeast-facing slopes (see Fig. 1).

Although it is highly speculative, results from our study suggest that, at least across the 35 ha scale of WS4, weathering may represent an ultimate control on nitrification. More highly weathered soils typically have higher clay content (Jenny 1980), and clay content was negatively correlated with net nitrification among our samples site, a relationship that was not substantially altered by freezing treatment (Fig. 5). This is consistent with conclusions of Gilliam et al. (2005), a study that included the LN and HN sites as part of a different gradient study at FEF. They found that exchangeable Al, another indicator of weathering status of soil (Troeh and Thompson 2005), was highest at LN (713 $\mu \mathrm{g} \mathrm{Al} \mathrm{g}^{-1}$ soil) and lowest at HN sites (149 $\mu \mathrm{g} \mathrm{Al} \cdot \mathrm{g}$ soil $\left.^{-1}\right)$. Although our work was carried out on a much smaller spatial scale, these conclusions are also consistent with those of Reich et al. (1997), who examined factors affecting net $\mathrm{N}$ mineralization across 50 forest stands at six sites in Wisconsin and Minnesota. They discovered that soil texture was more important than stand type in explaining spatial patterns of $\mathrm{N}$ mineralization.

\section{Implications for soil freezing in an N-saturated hardwood forest ecosystem}

The variety of responses of soil $\mathrm{N}$ dynamics to freezing, as shown in both field- and laboratory-based studies, precludes broad generalizations or predictions on effects of soil freezing in forest ecosystems. Although some of this arises from variation among studies in methodology used, much of it is likely the result of $(i)$ intersite variation in $\mathrm{N}$ status 
and soil microbial communities, (ii) site-specific factors that most profoundly influence those communities, and (iii) variable microbial response to freezing. Results of our study, a laboratory-based experiment that employed a field-based gradient in net nitrification that was largely maintained regardless of experimental treatment, suggest strongly that this is the case, at least at the 35 ha scale of a hardwood-dominated watershed. The intermediate temperatures used in this study $\left(0\right.$ and $\left.-20{ }^{\circ} \mathrm{C}\right)$ are not uncommon for ambient conditions at FEF. Long-term data from the Timber and Watershed Laboratory (USDA Forest Service) indicate that there were 1134 days $<0{ }^{\circ} \mathrm{C}$ over the decade of 1991-2000, during which time snowpack typically lasts a few days at a time (Adams et al. 1994).

One of the symptoms of $\mathrm{N}$ saturation is an increase in the predominance of net nitrification (Aber et al. 1998), and WS4 has been cited as one of the better examples of an Nsaturated ecosystem (Stoddard 1994; Peterjohn et al. 1996; Gress et al. 2007). Our results suggest that soil freezing at temperatures commonly experienced at this site can further increase net nitrification in soils already exhibiting high nitrification from $\mathrm{N}$ saturation, potentially exacerbating problems associated with $\mathrm{N}$ saturation, such as decreased growth rates of dominant hardwood species, which has been demonstrated at FEF (May et al. 2005; DeWalle et al. 2006).

Another characteristic of $\mathrm{N}$ saturation is high relative nitrification. That is, as $\mathrm{N}$ status increases, the amount of $\mathrm{N}$ mineralized from organic to inorganic forms that eventually become nitrified increases (Gilliam et al. 2001a, 2001b, 2004; Fenn et al. 2005), a pattern also supported by our data. However, net $\mathrm{N}$ mineralization increased in response to freezing to a degree greater than net nitrification at all sites other than HN. Thus, response of $\mathrm{N}$ mineralization to freezing may differ greatly from that of nitrification, suggesting that soil freezing may serve to decouple two processes of the soil $\mathrm{N}$ cycle that are otherwise tightly linked at our site.

Finally, because our sample sites represent discrete areas (i.e., subcatchments) within WS4, the $\mathrm{N}$ gradient represents a degree of spatial heterogeneity of $\mathrm{N}$ availability within the watershed. Thus, it is possible, based on results shown in Fig. $3 a$ wherein there were no longer significant differences in net $\mathrm{N}$ mineralization among sites at $-20{ }^{\circ} \mathrm{C}$, that one of the effects of freezing at temperatures quite common to the region may be to decrease the spatial heterogeneity of $\mathrm{N}$ mineralization in the watershed. This is a response with relevance to forest biodiversity. For example, Gilliam (2007) found that up to $90 \%$ of plant biodiversity of temperate forest ecosystems is found in the herbaceous layer, a vegetation stratum that is sensitive to spatial and temporal variation in soil $\mathrm{N}$ availability. It has been suggested that decreases in spatial heterogeneity of soil $\mathrm{N}$ can lead to decreases in herb layer diversity (the "N homogeneity hypothesis", see Gilliam 2006; Bobbink et al. 2010). Accordingly, the effects of soil freezing might have direct implications for biodiversity in forest ecosystems.

\section{Acknowledgements}

We appreciate the field assistance of Bill Peterjohn and Ian S. Gilliam in locating sample sites in the field. We thank Mary Beth Adams for logistical support. We are indebted to Jeff May and two anonymous reviewers for improvements in the manuscript following critical readings of earlier versions.

\section{References}

Abdel-Fatah, O.M., Elsayed, M.A., and Elshafei, A.M. 2003. Properties of a purine-ribonucleoside deaminase from Aspergillus phoenicis extracts. Adv. Food Sci. 25: 143-149.

Aber, J.W., McDowell, W., Nadelhoffer, K., Magill, A., Berntson, G., Kamakea, M., McNulty, S., Currie, W., Rustad, L., and Fernandez, I. 1998. Nitrogen saturation in temperate forest ecosystems. Bioscience, 48(11): 921-934. doi:10.2307/1313296.

Adams, M.B., Kochenderfer, J.N., Wood, F., Angradi, T., and Edwards, P. 1994. Forty years of hydrometeorological data from the Fernow Experimental Forest, West Virginia. U.S. For. Serv. Gen. Tech. Rep. NE-184.

Allen-Morley, C.R., and Coleman, D.C. 1989. Resilience of soil biota in various food webs to freezing perturbations. Ecology, 70(4): 1127-1141. doi:10.2307/1941381.

Austnes, K., and Vestgarden, L.S. 2008. Prolonged frost increases release of $\mathrm{C}$ and $\mathrm{N}$ from a montane heathland soil in southern Norway. Soil Biol. Biochem. 40(10): 2540-2546. doi:10.1016/j. soilbio.2008.06.014.

Barnett, T.P., Adam, J.C., and Lettenmaier, D.P. 2005. Potential impacts of a warming climate on water availability in snowdominated regions. Nature, 438(7066): 303-309. doi:10.1038/ nature04141. PMID:16292301.

Bobbink, R., Hicks, K., Galloway, J., Spranger, T., Alkemade, R., Ashmore, M., Bustamante, M., Cinderby, S., Davidson, E., Dentener, F., Emmett, B., Erisman, J.-W., Fenn, M., Gilliam, F., Nordin, A., Pardo, L., and de Vries, W. 2010. Global assessment of nitrogen deposition effects on terrestrial plant diversity effects of terrestrial ecosystems: a synthesis. Ecol. Appl. 20. In press.

Bonilla, D., and Rodà, F. 1992. Soil nitrogen dynamics in a holm oak forest. Vegetatio, 99-100: 247-257. doi:10.1007/BF00118231.

Campbell, J.L., Driscoll, C.T., Eagar, C., Likens, G.E., Siccama, T.G., Johnson, C.E., Fahey, T.J., Hamburg, S.P., Holmes, R.T., Bailey, A.S., and Buso, D.C. 2007. Long-term trends from ecosystem research at the Hubbard Brook Experimental Forest. U.S. For. Serv. Gen. Tech. Rep. NRS-17.

Christopher, S.F., Shibata, H., Ozawa, M., Nakagawa, Y., and Mitchell, M.J. 2008. The effect of soil freezing on N cycling: comparison of two headwater subcatchments with different vegetation and snowpack conditions in the northern Hokkaido Island of Japan. Biogeochemistry, 88(1): 15-30. doi:10.1007/ s10533-008-9189-4.

Cooke, J.G. 1990. Rapid freezing effects on nitrification and denitrification enzyme activity in saturated soil and aquatic sediments. Soil Biol. Biochem. 22(8): 1171-1172.

DeLuca, T.H., Keeney, D.R., and McCarty, G.W. 1992. Effect of freeze-thaw events on mineralization of soil nitrogen. Biol. Fertil. Soils, 14(2): 116-120. doi:10.1007/BF00336260.

DeWalle, D.R., Kochenderfer, J.N., Adams, M.B., Miller, G.W., Gilliam, F.S., Wood, F., Odenwald-Clemens, S.S., and Sharpe, W.E. 2006. Vegetation and acidification. In The Fernow Watershed Acidification Study. Series: Environmental Pollution. Vol. 11. Edited by M.B. Adams, D.R. DeWalle, and J. Hom. Springer, New York. pp. 137-188.

Fahey, T.J., and Lang, G.E. 1975. Concrete frost along an elevational gradient in New Hampshire. Can. J. For. Res. 5(4): 700 705. doi:10.1139/x75-096.

Fenn, M.E., Poth, M.A., Terry, J.D., and Blubaugh, T.J. 2005. Nitrogen mineralization and nitrification in a mixed-conifer forest in southern California: controlling factors, fluxes, and nitrogen fertilization response at a high and low nitrogen deposition site. Can. J. For. Res. 35(6): 1464-1486. doi:10.1139/X05-068.

Fitzhugh, R.D., Driscoll, C.T., Groffman, P.M., Tierney, G.L., Fahey, T.J., and Hardy, J.P. 2001. Effects of soil freezing distur- 
bance on soil solution nitrogen, phosphorus, and carbon chemistry in a northern hardwood ecosystem. Biogeochemistry, 56(2): 215-238. doi:10.1023/A:1013076609950.

Gilliam, F.S. 2006. Response of the herbaceous layer of forest ecosystems to excess nitrogen deposition. J. Ecol. 94(6): 11761191. doi:10.1111/j.1365-2745.2006.01155.x.

Gilliam, F.S. 2007. The ecological significance of the herbaceous layer in forest ecosystems. Bioscience, 57(10): 845-858. doi:10. 1641/B571007.

Gilliam, F.S., and Richter, D.D. 1985. Increases in extractable ions in infertile Aquults caused by sample preparation. Soil Sci. Soc. Am. J. 49: 1576-1578.

Gilliam, F.S., and Richter, D.D. 1988. Correlations between extractable $\mathrm{Na}, \mathrm{K}, \mathrm{Mg}, \mathrm{Ca}, \mathrm{P}$ and $\mathrm{N}$ from fresh and dried samples of two Aquults. J. Soil Sci. 39(2): 209-214. doi:10.1111/j.13652389.1988.tb01207.x.

Gilliam, F.S., Yurish, B.M., and Adams, M.B. 1996. Ecosystem nutrient responses to chronic nitrogen inputs at Fernow Experimental Forest, West Virginia. Can. J. For. Res. 26(2): 196-205. doi:10.1139/x26-023.

Gilliam, F.S., Yurish, B.M., and Adams, M.B. 2001a. Temporal and spatial variation of nitrogen transformations in nitrogensaturated soils of a central Appalachian hardwood forest. Can. J. For. Res. 31(10): 1768-1785. doi:10.1139/cjfr-31-10-1768.

Gilliam, F.S., Somerville, C.C., Lyttle, N.L., and Adams, M.B. $2001 b$. Factors influencing spatial variability in nitrogen processing in nitrogen-saturated soils. ScientificWorld J. 1(Suppl. 2): 505-513. PMID:12805879.

Gilliam, F.S., Dick, D.A., Kerr, M.L., and Adams, M.B. 2004. Effects of silvicultural practices on soil carbon and nitrogen in a nitrogen saturated central Appalachian (USA) hardwood forest ecosystem. Environ. Manag. 32(Suppl. 1): S108-S119. doi:10. 1007/s00267-003-9121-6.

Gilliam, F.S., Lyttle, N.L., Thomas, A., and Adams, M.B. 2005. Soil variability along a nitrogen mineralization and nitrification gradient in a nitrogen-saturated hardwood forest. Soil Sci. Soc. Am. J. 69: 247-256.

Gress, S.E., Nichols, T.D., Northcraft, C.C., and Peterjohn, W.T. 2007. Nutrient limitation in soils exhibiting differing nitrogen availabilities: what lies beyond nitrogen saturation? Ecology, 88(1): 119-130. doi:10.1890/0012-9658(2007)88[119:NLISED]2. 0.CO;2. PMID: 17489460.

Groffman, P.M., Driscoll, C.T., Fahey, T.J., Hardy, J.P., Fitzhugh, R.D., and Tierney, G.L. 2001a. Colder soils in a warmer world: a snow manipulation study in a northern hardwood forest ecosystem. Biogeochemistry, 56(2): 135-150. doi:10.1023/ A:1013039830323.

Groffman, P.M., Driscoll, C.T., Fahey, T.J., Hardy, J.P., Fitzhugh, R.D., and Tierney, G.L. 2001b. Effects of mild winter freezing on soil solution nitrogen and carbon dynamics in a northern hardwood forest. Biogeochemistry, 56(2): 191-213. doi:10. 1023/A:1013024603959.

Harding, D.E., and Ross, D.J. 1964. Some factors in low-temperature storage influencing the mineralisable-nitrogen of soils. J. Sci. Food Agric. 15(12): 829-834. doi:10.1002/jsfa.2740151203.

Hardy, J.P., Groffman, P.M., Fitzhugh, R.D., Henry, K.S., Welman, A.T., Demers, J.D., Fahey, T.J., Driscoll, C.T., Tierney, G.L., and Nolan, S. 2001. Snow depth manipulation and its influence on soil frost and water dynamics in a northern hardwood forest. Biogeochemistry, 56(2): 151-174. doi:10.1023/A:1013036803050.

Hentschel, K., Borken, W., Zuber, T., Bogner, C., Huwe, B., and Matzner, E. 2009. Effects of soil frost on nitrogen net mineralization, soil solution chemistry and seepage losses in a temperate forest soil. Glob. Change Biol. 15(4): 825-836. doi:10.1111/j. 1365-2486.2008.01753.x.

Jenny, H. 1980. The soil resource. Springer-Verlag, New York.

Joseph, G.H., and Henry, A.L. 2008. Soil nitrogen leaching losses in response to freeze-thaw cycles and pulsed warming in a temperate old field. Soil Biol. Biochem. 40: 1947-1953. doi:10. 1016/j.soilbio.2008.04.007.

Lynch-Stieglitz, M. 1994. The development and validation of a simple snow model for the GISS GCM. J. Clim. 7(12): 1842-1855. doi:10.1175/1520-0442(1994)007<1842:TDAVOA>2.0.CO;2.

May, J.D., Burdette, E., Gilliam, F.S., and Adams, M.B. 2005. Interspecific divergence in foliar nutrient dynamics and stem growth in a temperate forest in response to chronic nitrogen inputs. Can. J. For. Res. 35(5): 1023-1030. doi:10.1139/X05-036.

Morley, C.R., Trofymow, J.A., Coleman, D.C., and Cambardella, C. 1983. Effects of freeze-thaw stress on bacterial populations in soil microcosms. Microb. Ecol. 9(4): 329-340. doi:10.1007/ BF02019022.

Peterjohn, W.T., Adams, M.B., and Gilliam, F.S. 1996. Symptoms of nitrogen saturation in two central Appalachian hardwood forest systems. Biogeochemistry, 35(3): 507-522. doi:10.1007/ BF02183038.

Peterjohn, W.T., Foster, C.J., Christ, M.J., and Adams, M.B. 1999. Patterns of nitrogen availability within a forested watershed exhibiting symptoms of nitrogen saturation. For. Ecol. Manag. 119(1-3): 247-257. doi:10.1016/S0378-1127(98)00526-X.

Rech, J.A., Reeves, R.W., and Hendricks, D.M. 2001. The influence of slope aspect on soil weathering processes in the Springerville volcanic field, Arizona. Catena, 43(1): 49-62. doi:10. 1016/S0341-8162(00)00118-1.

Reich, P.B., Grigal, D.F., Aber, J.D., and Gower, S.T. 1997. Nitrogen mineralization and productivity in 50 hardwood and conifer stands on diverse soils. Ecology, 78: 335-347.

Robertson, G.P. 1982. Nitrification in forested ecosystems. Philos. Trans. R. Soc. Lond. B Biol. Sci. 296(1082): 445-457. doi:10. 1098/rstb.1982.0019.

Schimel, J.P., Bilbrough, C., and Welker, J.M. 2004. Increased snow depth affects microbial activity and nitrogen mineralization in two Arctic tundra communities. Soil Biol. Biochem. 36(2): 217-227. doi:10.1016/j.soilbio.2003.09.008.

Schmidt, S.K., Wilson, K.L., Monson, R.K., and Lipson, D.A. 2009. Exponential growth of "snow molds" at sub-zero temperatures: an explanation for high beneath-snow respiration rates and $Q_{10}$ values. Biogeochemistry, 95(1): 13-21. doi:10.1007/ s10533-008-9247-y.

Skogland, T., Lomeland, S., and Goksøyr, J. 1988. Respiratory burst after freezing and thawing of soil: experiments with soil bacteria. Soil Biol. Biochem. 20(6): 851-856. doi:10.1016/ 0038-0717(88)90092-2.

Stoddard, J.L. 1994. Long-term changes in watershed retention of nitrogen: its causes and aquatic consequences. In Environmental chemistry of lakes and reservoirs. Edited by L.A. Baker. ACS Advances in Chemistry Series No. 237. American Chemical Society, Washington, D.C. pp. 223-294.

Tajchman, S.J., Harris, M.H., and Townsend, E.C. 1988. Variability of the radiative index of dryness in an Appalachian watershed. Agric. For. Meteorol. 42(2-3): 199-207. doi:10.1016/ 0168-1923(88)90077-9.

Tierney, G.L., Fahey, T.J., Groffman, P.M., Hardy, J.P., Fitzhugh, R.D., and Driscoll, C.T. 2001. Soil freezing alters fine root dynamics in a northern hardwood forest. Biogeochemistry, 56(2): 175-190. doi:10.1023/A:1013072519889. 
Troeh, F.R., and Thompson, L.M. 2005. Soils and soil fertility. 6th ed. Wiley-Blackwell, Hoboken, N.J.
Zar, J. 1999. Biostatistical analysis. 4th ed. Prentice-Hall, Englewood Cliffs, N.J. 